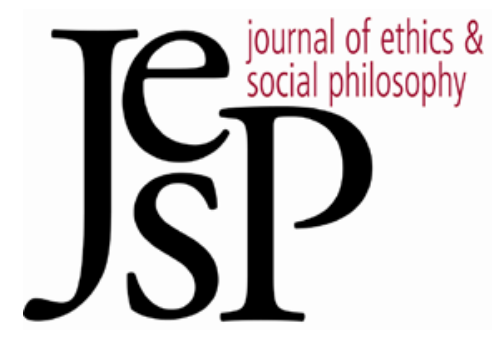

\title{
Moral Error Theory and THE Argument From EPISTEMIC REASONS
}

BY RICHARD ROWLAND

Journal of Ethics \& SOCIAL PhILOSOPHY

VOL. 7, NO. 1| JANUARY 2013 URL: WWW.JESP.ORG COPYRIGHT @ RICHARD ROWLAND 2013 


\section{Moral Error Theory and the Argument from Epistemic Reasons}

Richard Rowland

\section{The Argument from Epistemic Reasons}

HE MORAL ERROR THEORY INVOLVES two components:
a conceptual component and an ontological component. According to the
conceptual component, moral facts and claims entail facts and claims about categorical normative reasons. According to the ontological component, there are no categorical normative reasons. ${ }^{1}$ Recently several philosophers, most notably Terence Cuneo, have tried to argue against the moral error theory on the grounds that it entails that there are no epistemic reasons for belief. ${ }^{2}$ One way, which is not exactly Cuneo's way, of arguing against the error theory on these grounds I call the Argument from Epistemic Reasons. 3 According to this argument:

(1) According to the moral error theory, there are no categorical normative reasons.

(2) If there are no categorical normative reasons, then there are no epistemic reasons for belief.

(3) But there are epistemic reasons for belief.

(4) So there are categorical normative reasons $(2,3)$.

(5) So the error theory is false $(1,4)$.

In this paper I provide a thorough articulation and defense of the argument from epistemic reasons against the moral error theory. In section 2, I articulate and defend premises (1) and (2). In section 3, I provide an argument for premise (3). And in section 4, I defend the argument from epistemic reasons from some objections to the argument as a whole.

\footnotetext{
${ }^{1}$ See Jonas Olson (2010) "In Defense of Moral Error Theory," in Michael Brady, ed., New Waves in Metaethics, Basingstoke: Palgrave Macmillan, 62-84, 62; Richard Joyce (2011) The Myth of Morality, Cambridge: Cambridge University Press, 37-45; J. L. Mackie (1977) Ethics: Inventing Right and Wrong, New York: Penguin, 29; and Richard Garner (1990) "On the Genuine Queerness of Moral Properties and Facts," Australasian Journal of Philosophy 68: 137-46, 142.

2 See Terence Cuneo (2007) The Normative Web: An Argument for Moral Realism, Oxford: Oxford University Press, chs. 1-4 and Philip Stratton-Lake (2002) "Introduction," in David Ross, The Right and the Good, Oxford: Clarendon, xxv-xxvi.

${ }^{3}$ Cuneo argues that the fact that the moral error theory entails that there are no epistemic reasons for belief leads to three undesirable results for the moral error theory: (1) The view that there are no epistemic reasons is either self-defeating, and so we have no (sufficient) reason to believe it, or it implies that there are no epistemic reasons and, a fortiori, we have no reason to believe it; (2) the view that there are no epistemic reasons is either self-defeating or "implies a radical version of epistemological skepticism according to which no entity can display an epistemic merit or demerit"; and (3) either the view that there are no epistemic reasons for belief is self-defeating "or it implies that there could be no arguments for anything." See Cuneo (2007: 117-22). For responses to Cuneo's particular argument see Jonas Olson (2011) "Error Theory and Reasons for Belief," in Andrew Reisner and Aasbjørn Steglich-Petersen, eds., Reasons for Belief, Cambridge: Cambridge University Press, 75-93.
} 
In section 2, I defend the claim that if there are no categorical normative reasons, then there are no epistemic reasons for belief. The most promising challenge to this claim holds that epistemic reasons are not really normative because epistemic reasons can be reductively analyzed in terms of nonnormative facts about probability-raising but categorical moral reasons for action cannot be reductively analyzed in terms of nonnormative facts. I demonstrate that the arguments against reductively analyzing moral reasons in terms of nonnormative properties have analogues that are equally good arguments against reductively analyzing epistemic reasons in terms of nonnormative properties.

Some defenders of the error theory do not accept the third premise of the argument from epistemic reasons - that is, some defenders of the error theory claim that there are no epistemic reasons for belief. ${ }^{4}$ In section 3, I argue that if there are no epistemic reasons for belief, then no one knows anything. My argument for this is that if $S$ knows $p$, then there is some epistemic justification for $S$ to believe $p$, and if there is some epistemic justification for $S$ to believe that $p$, then there is an epistemic reason for $S$ to believe $p$. So, if $S$ knows $p$, there is an epistemic reason for $S$ to believe $p$. And so in order to show that there are epistemic reasons, all we need to do is to show that someone knows something. And we can do this because if someone believes that there is thought, they know that there is thought, and many of us know that we do not know everything; it is hard to understand how we could not know these things. So there are epistemic reasons for belief.

It would not be distorting to reduce my version of the argument from epistemic reasons against the error theory to the argument that the error theory entails that no one knows anything, but some people do know something, so the error theory is false. It might seem that arguing against the error theory on the grounds that it entails that no one knows anything is just providing a Moorean argument against the moral error theory. In section 4, I show that, even if my argument against the error theory is indeed a Moorean one, it avoids objections that Bart Streumer, Jonas Olson and Tristram McPherson have made to previous Moorean arguments against the error theory. I also argue that my argument against the error theory is more powerful than Moore's argument against external world skepticism.

\section{The Moral Error Theory Entails that There Are No Epistemic Reasons.}

According to the first two premises of the argument from epistemic reasons:

(1) According to the moral error theory, there are no categorical normative reasons.

(2) If there are no categorical normative reasons, then there are no epistemic reasons for belief.

${ }^{4}$ See Olson (2011), and Bart Streumer (forthcoming) "Can We Believe the Error Theory?" Journal of Philosophy. 
These two premises amount to the following claim: The moral error theory entails that there are no epistemic reasons for belief.

According to the moral error theory's ontological component, there are no categorical normative reasons. ${ }^{5}$ Categorical normative reasons are normative reasons for agents to do things or have certain attitudes irrespective of their desires, aims, wants and feelings, and the roles in which they happen to find themselves; these reasons for agents to do things are ontologically/existentially independent of these agents' desires, aims, wants, feelings and roles. ${ }^{6}$ In contrast, hypothetical normative reasons are reasons for agents to do things or have certain attitudes that are not independent of these agents' desires, aims or roles. For instance, if, but only if, you like blueberry muffins, there is a reason for you to buy some.

It seems that moral facts and claims entail categorical rather than hypothetical reasons because agents' desires and goals do not seem relevant to their moral reasons. If two people are in the same situation, they have the same moral reasons to act. For instance, if two people see a child close to drowning in the water, they both have moral reasons to try to save the child, regardless of differences in their desires, interests or goals.

But it is not only moral reasons that seem categorical: Epistemic reasons for belief also seem categorical. It seems that the fact that there are dinosaur bones around is a reason for everyone to believe that dinosaurs once roamed the earth, regardless of whether they want to believe this or not. In general, two agents in the same epistemic situation - that is, with the same evidence and background beliefs - seem to have the "same reasons for believing any given proposition, regardless of possible differences in their personal goals." 7 So, it seems that the moral error theory's ontological component, the claim that there are no categorical reasons, entails that there are no epistemic reasons for belief as well as no moral reasons for action. In the rest of this section, I consider many ways it might be argued and several ways it has been argued that the moral error theory does not entail that there are no epistemic reasons for belief.

Moral error theorists might claim that, although epistemic reasons for belief and moral reasons are alike in being categorical, they are unlike one another in that moral reasons are reasons to perform acts and epistemic reasons are reasons for belief, and thus there can be epistemic reasons even if there are no moral reasons. But moral error theorists are not, qua error theorists, skeptics about the facts (or propositions) that we take to be moral reasons. ${ }^{8}$ Nor are they skeptics about the acts for which we

\footnotetext{
5 Supra, n. 1.

${ }^{6}$ See, for instance, Olson (2010: 64-65).

7 Peter Railton (2003) "On the Hypothetical and Non-Hypothetical in Reasoning About Belief and Action," in Facts, Values, and Norms: Essays Towards a Morality of Consequence, Cambridge: Cambridge University Press, 293-321, 293. See also Thomas Kelly (2003) "Epistemic Rationality as Instrumental Rationality: A Critique," Philosophy and Phenomenological Research 66: 612-40, 616; Olson (2011: 77-82); and Stratton-Lake (2002: xxv-xxvi).

${ }_{8}^{8}$ Error theorists are skeptics with regard to some facts that we might take to be reasons: We might think that the fact that torture is wrong is a reason not to torture, and error theorists are skeptics with regard to the fact that torture is wrong. However, error theo-
} 
take these facts to be reasons. Rather, moral error theorists are skeptics about the reason relation that we take to hold between the facts and the acts. Some fact's being a normative reason for an act is just its having the relational property of being a normative reason for an act. What moral error theorists are skeptical about is precisely this normative warranting relation between facts and acts. Moral error theorists claim that categorical normative warranting relations do not exist. But if the moral error theory's skepticism is about categorical normative relations, they cannot be skeptical about categorical normative relations that have acts as one of their relata, but not about categorical normative relations that have beliefs as one of their relata. ${ }^{9}$

Moral error theorists might claim that epistemic reasons are not really categorical reasons but are merely hypothetical reasons. If error theorists can coherently hold that moral reasons for action are categorical reasons but epistemic reasons for belief are not categorical reasons, then the moral error theory does not entail that there are no epistemic reasons.

However, moral error theorists cannot hold both that:

There are epistemic reasons in the way that we understand them but these epistemic reasons are hypothetical reasons.

And that:

There are no moral reasons in the way that we understand them because there are only hypothetical reasons.

Error theorists are not skeptical of hypothetical reasons. ${ }^{10}$ But they hold that if there are only hypothetical reasons, our understanding of morality is radically mistaken, because our understanding of morality entails that there are categorical reasons. ${ }^{11}$ However, our understanding of epistemic reasons and justification also entails that there are categorical reasons. As I said, it seems that there is reason for everyone to believe that dinosaurs once roamed the earth regardless of what they want to believe; there would still be reason for me to believe that I am in my office writing right now even if believing this made me extremely unhappy or did not promote any of my desires. Two agents in the same epistemic situation seem to have the same epistemic reasons, regardless of their desires or goals or

rists' skepticism regarding this fact derives from their skepticism regarding the categorical relationship between facts, agents and acts that moral facts, such as the fact that torture is wrong, entail.. So if, for instance, the negative buck-passing thesis regarding wrongness and other moral facts holds - that is, if the fact that an act is right or wrong is never a reason to respond to it but it is rather the other properties of that act that are reasons to respond to it - then error theorists would still be skeptics with regards to moral reasons.

${ }^{9}$ See Stratton-Lake (2002: xxv-xxvi).

${ }^{10}$ Jonas Olson argues that in order to refrain from skepticism about hypothetical reasons, defenders of the error theory must hold that hypothetical reasons can be reductively analyzed in terms of desires, aims or roles. See Olson (2010, \5). I assume that Olson is right about this but that reductively analyzing hypothetical reasons in terms of desires, aims or roles fits with our understanding of hypothetical reasons.

11 See Joyce (2011: 42-43) and Olson (2010: 64-65). 
the roles that they find themselves in, just as two people who see a child drowning seem to have moral reasons to save the child regardless of their desires, goals or roles. So, if there are only hypothetical reasons for belief, our understanding of epistemic reasons is just as badly mistaken as our understanding of morality and moral reasons is if there are only hypothetical reasons for action. ${ }^{12}$

Rather than arguing that epistemic reasons are conditional on particular desires, however, Hilary Kornblith argues that epistemic reasons can be reduced to hypothetical reasons that are conditional on our having any desires at all. According to Kornblith, whatever we desire $\mathrm{R}$ is a reason for us to believe $p$ if $\mathrm{R}$ improves the probability that $p$ (or does so strongly), because it promotes our desires to some extent, whatever these desires happen to $b e$, if we have cognitive processes that are truth-conducive. ${ }^{13}$

But Kornblith's view is still contrary to our ordinary understanding of epistemic reasons. Suppose that an agent, Ella, desires only psychological contentment, and only ever desires this, and that Ella is extraordinarily psychologically fragile. Because of her fragility, in order for Ella to be psychologically content she would have to isolate herself from almost all other agents and only engage in extremely simple tasks. Ella must block off from consideration a vast number of propositions regarding her own psychological state, the state of the world, and the status of her friends and family among other things because she finds considering these matters extremely disturbing. Suppose that Ella is extremely successful at blocking out all these considerations over the course of her life. In this case, if Kornblith is right, there is no reason for Ella to believe many propositions about the world, herself, and her friends and family. For instance, even if she is well aware of $R$, and $R$ is extremely good evidence that her father has cancer, there is no reason at all for Ella to believe that her father has cancer. But this is exactly what we do not think. We think that $R$ is at least some reason for Ella to believe that her father has cancer - if it is extremely good evidence for this - regardless of the effects this will have on her. These effects might generate pragmatic reasons that vastly outweigh the reason to believe that her father has cancer, but they do not stop there being a reason for Ella to believe this. ${ }^{14}$ So, Kornblith's proposal cannot be used to show that epistemic reasons can be reduced to hypothetical reasons consistent with our understanding of epistemic reasons but moral reasons cannot be reduced to hypothetical reasons consistent with our understanding of moral reasons. ${ }^{15}$

Some people think that claims about etiquette and fashion, for example, entail categorical normative reasons, because the requirements of etiquette and fashion are categorical: They apply to everyone regardless of

\footnotetext{
${ }^{12}$ Cf. Cuneo (2007: 204-06). This is not to say, with error theorists, that our understanding of either is mistaken if there are only hypothetical reasons.

13 See Hilary Kornblith (2001) Knowledge and Its Place in Nature, Oxford: Oxford University Press, 158-59.

${ }^{14}$ I take this argument from Cuneo (2007: 207-08).

15 See Ibid., 208-12.
} 
their desires, interests or goals. ${ }^{16}$ For instance, according to fashion there is a reason for everyone not to wear white after Labor Day, and this applies to you regardless of whether you care about fashion or not. If claims about etiquette and fashion entail categorical normative reasons, then the moral error theory should be put in different terms. Richard Joyce claims that moral imperatives "(putatively) bind persons, in a way that etiquette does not bind" them. ${ }^{17}$ So we might see the error theory in a different way. We might say that according to the error theory's conceptual component, moral facts and claims entail facts and claims about authoritatively binding categorical normative reasons. And according to its ontological component, there are no authoritatively binding categorical normative reasons.

Error theorists might be tempted to claim that epistemic reasons do not have the same authority, bindingness, or practical "oomph" as Joyce sometimes puts it, as moral reasons. It seems that by authority, bindingness and "oomph," Joyce just means whatever it is that makes moral reasons seem more binding and important, regardless of agents' desires, than the reasons of fashion and etiquette. But if this is all that Joyce means by authority and "oomph," then epistemic reasons will have authority and "oomph" too, since epistemic reasons seem very different from the reasons of etiquette and fashion. Epistemic reasons seem to apply to everyone in a more important sense than the reasons and requirements of fashion and etiquette. And it seems that what there is a reason to believe does not depend entirely on the conventions and practices of a community; if you have sufficient evidence that something is the case, there is sufficient reason for you to believe it, regardless of what the rest of your community thinks. ${ }^{18}$

16 See Stephen Finlay (2006) "The Reasons that Matter," Australasian Journal of Philosophy 84: 1-20.

${ }^{17}$ Joyce (2011: 37).

18 It might seem that Joyce has something different in mind when he discusses authority and practical "oomph." It might seem that Joyce means that moral reasons are authoritatively binding in the sense that if an agent does not do what there is overriding moral reason to do, then they are at fault in a particularly personal way - that is, they are morally blameworthy, or the appropriate subject of anger. I doubt that epistemic reasons for belief have this kind of authoritative bindingness, and I doubt that failing to believe what there is overriding epistemic reason to believe makes one the appropriate object of this type of hostile reactive attitude, although cf. Cuneo (2007: 98). However, this moral blameworthiness is only attached to deontic concepts such as wrongness, obligation and duty. If someone does something that is morally wrong, or if they breached an obligation, or did not do their duty, it might follow that they are the appropriate subject of hostile reactive attitudes, such as anger or moral blame. If someone does not do something that would have been good, or that would have produced the most good, it does not follow that they are to that extent the appropriate object of moral blame, anger or other hostile reactive attitudes. But the error theory is intended as a metaethical view that covers all moral and ethical values and all moral and ethical categorical reasons, not only deontic categorical reasons. Mackie, for instance, was concerned with values in general, Charles Pigden is concerned with the predicative use of good (or good simpliciter) and according to Joyce, error theorists are concerned with "goodness, evil, virtue, etc." See Mackie (1977); Charles Pigden (1990) "Geach on Good," Philosophical Quarterly 40: 129-54, 130; and Richard Joyce (forthcoming) "The Evolutionary Debunking of Morality," in Joel Feinberg and Russ Shafer-Landau, eds., Reason and Responsibility, 15th edition. So, Joyce cannot mean that moral reasons are tied up with reactive attitudes and fault 
Bart Streumer articulates the error theory in a slightly different way. According to Streumer, the error theory's conceptual component holds that moral facts and claims entail facts and claims about irreducibly normative reasons, which are irreducibly normative properties. According to the ontological component there are no irreducibly normative properties. On this view, the reasons of fashion or etiquette are not problematic because they can be reduced to nonnormative sociological facts about practices or conventions. But moral reasons cannot be reduced to nonnormative facts and so entail that there are irreducibly normative properties. ${ }^{19}$

Streumer's way of understanding the error theory guides us to the most promising strategy for arguing that the moral error theory does not entail that there are no epistemic reasons. A defender of Streumer's particular way of understanding the error theory could argue that moral reasons are irreducibly normative but epistemic reasons are not irreducibly normative. Those who hold that the error theory concerns categorical normative reasons can adopt the same strategy: They can argue that the error theory's ontological component does not entail that there are no epistemic reasons for belief because epistemic reasons are not categorical normative reasons. The general idea behind this argument is that epistemic reasons are not really normative reasons because they can be reductively analyzed in terms of nonnormative properties. Moral reasons are irreducibly normative and so cannot be reductively analyzed in terms of nonnormative facts (for example, facts about desires or pleasure promotion.) But epistemic reasons for belief can be reductively analyzed in terms of nonnormative facts, such as facts about probability raising or reliable indication. This view of the reducibility of epistemic reasons and the irreducibility of moral reasons is equivalent to the view that a nonnormative conceptual or metaphysical (analytic or synthetic) analysis of moral reasons is implausible, but a nonnormative conceptual or metaphysical analysis of epistemic reasons is not implausible. ${ }^{20}$

Chris Heathwood has recently argued that a conceptual analysis of epistemic reasons in nonnormative terms is more plausible than a conceptual analysis of moral reasons in nonnormative terms. Heathwood holds that Moore's open question argument casts doubt on naturalistic conceptual analyses of moral reasons and other moral notions, but the epistemic analogue of the open question argument does not cast doubt on naturalistic conceptual analyses of epistemic reasons. According to Heathwood's understanding of the open question argument, for any pu-

when he claims that moral reasons have a practical "oomph" or authoritative bindingness.

19 See Streumer (forthcoming) and Bart Streumer (2008) “Are There Irreducibly Normative Properties?” Australasian Journal of Philosophy 86: 537-61, 559-60.

20 Two authors who endorse this view are Chris Heathwood (2009) "Moral and Epistemic Open-Question Arguments," Philosophical Books 50: 83-98 and James Lenman (2008) "Review of Terence Cuneo, The Normative Web: An Argument for Moral Realism," Notre Dame Philosophical Reviews. This view also frequently comes up in discussion. This is not C. S. Jenkins's view. Jenkins holds that a synthetic naturalist account of moral facts is plausible and argues for a synthetic naturalist account of epistemic facts. See C. S. Jenkins (2007) "Epistemic Norms and Natural Facts," American Philosophical Quarterly 44: 259-72. 
tative definition of a moral predicate $M$ in terms of a natural predicate $N$, it is not self-contradictory to claim that $X$ is $N$ but $X$ is not $M$. So, for instance, it is not self-contradictory to claim that $X$ is something that we desire to desire, but $X$ is not good. And it is not self-contradictory to claim that $\phi$-ing would cause some pleasure, but there is no moral reason to $\phi .{ }^{21}$ But if no such claims are self-contradictory, then moral predicates, such as "is a moral reason," do not mean the same thing as natural predicates, such as "is something that would cause some pleasure." So, moral predicates do not mean the same as natural predicates..$^{22}$

According to the epistemic analogue of the open question argument, for any putative definition of an epistemic predicate $E$ in terms of a natural predicate $N$, it is not self-contradictory to claim that $X$ is $N$ but $X$ is not $E$. So, it is not self-contradictory to claim that $R$ raises the probability that $p$, but there is no epistemic reason to believe $p$. If no such claims are self-contradictory, then epistemic predicates, such as "is an epistemic reason to believe $p$," do not mean the same thing as natural predicates, such as "is a fact that raises the probability that $p$." So, epistemic predicates do not mean the same as natural predicates. Heathwood claims that epistemic open question arguments are not compelling because claims, such as " $\mathrm{R}$ improves the probability that $p$, but there is no (epistemic) reason to believe $p$," have an air of incoherence about them "in a way that axiological statements - even such patently false ones like 'suffering is intrinsically good' - never do." ${ }_{23}$

But although some Bayesians hold that for $\mathrm{R}$ to be an (epistemic) reason to believe $p$ is just for $R$ to improve the probability that $p$, most people intuitively do not. If $R$ is the fact that $I$ am in my office today, then $R$ improves the probability that I will die in my office today. But it does not seem that the fact that I am in my office today is a reason to believe that I will die in my office today; I am perfectly healthy, and probably safer in my office than anywhere else. ${ }^{24} \mathrm{I}$ am certainly not contradicting myself when I claim that the fact that I am in my office today improves the probability that I will die in my office today, but is not an (epistemic) reason to believe that I will die in my office today.

Heathwood is not explicit about how he thinks that we should understand probability. ${ }^{25}$ It might be held that on some understanding of probability the fact that I am in my office today does not improve the probability that I will die in my office today. But there is no account of probability that does not entail this conclusion. On a subjective understanding of probability, $R$ raises the probability of $p$ if and only if a rational agent would have a greater degree of belief in $p$ given $R$ than not given $R$. And it is true that a rational agent will have a greater degree of

\footnotetext{
${ }^{21}$ Assume a natural predicate to be a nonnormative predicate, a causal predicate or a predicate used in the sciences.

22 See Heathwood (2009: 86).

23 Ibid., 90

24 See Peter Achinstein (2001) The Book of Evidence, Oxford: Oxford University Press, 70.

25 Although he seems to be drawn to an objective account, see Heathwood (2009: 93).
} 
belief that I will die in my office today given the fact that I am in my office today than not given this fact if this is all the information available.

On an objective understanding of probability, $R$ improves the probability of $p$ because of the relationship between $R$ and $p$, regardless of the relationship of $R$ and $p$ to agents. One way of specifying this objective relationship is in terms of frequency. $R$ improves the probability that $p$ if and only if the frequency of $p$ given $R$ is greater than the frequency of $p$ given not- $R$. On this understanding, the fact that I am in my office today does raise the probability that I will die in my office today, since the frequency of my dying in my office today is greater given that I am in my office today than the frequency of my dying in my office today not given the fact that I am in my office today. Another objective understanding of probability-raising is in terms of propensities and dispositions. On this view, $R$ improves the probability that $p$ if and only if $R$ has a disposition or propensity to cause $p$. But if I am in my office, I have a weak disposition to die in my office. So, on this view, the fact that I am in my office does raise the probability that I will die in my office. ${ }^{26}$

There is a general point here as well. It seems extremely intuitive to claim that the fact that I am in my office improves the probability of me dying there, and so it seems that any understanding of probability should hold that the fact that I am in my office today improves the probability of me dying there. So, whatever understanding of probability Heathwood might endorse, it seems that it is not contradictory to hold that the fact that I am in my office today improves the probability that I will die in my office today, but there is no epistemic reason for me to believe that I will die in my office today. ${ }^{27}$

But it might seem that there is a close-by conceptual analysis of epistemic reasons in terms of probability that avoids the problem that I have been discussing. Consider the following account of epistemic reasons:

For $R$ to be an epistemic reason to believe $p$ is just for the probability of $p$ given $R$ to be high. ${ }^{2}$

However, this analysis of epistemic reasons faces problems too. Suppose that my brother has regularly taken his wife's birth control pills over the

26 See Alan Hájek (2012) "Interpretations of Probability," The Stanford Encyclopedia of Philosophy, Summer 2012 edition, E. N. Zalta, ed., plato.stanford.edu/entries/probabilityinterpret, and Seth Yalcin (2010) "Probability Operators," Philosopby Compass 5(11): 91636, 917.

27 Of course, Heathwood could endorse an account of probability in terms of epistemic reasons. But then his argument would be trivial, for he would have only shown that it is incoherent to claim that $R$ is an epistemic reason to believe $p$, but $R$ is not an epistemic reason to believe $p$. And this conclusion cannot be used as a premise in an argument for anything, and certainly not the argument that epistemic reasons for belief can be reductively analyzed in terms of nonnormative properties. Heathwood also opposes such an account; see Heathwood (2009: 92-93).

28 This is modeled on Carnap's understanding of evidence; see Rudolf Carnap (1950) The Logical Foundations of Probability, Chicago: University of Chicago Press, and Victor DiFate (2007) “Evidence," The Internet Encyclopedia of Philosophy, www.iep.utm.edu, \$2(a). 
last year. In this case, the probability of my brother not being pregnant given the fact that he has taken his wife's birth control pills over the last year is high. But the fact that my brother has taken his wife's birth control pills over the last year is no reason at all to believe that he is not pregnant. ${ }^{29}$ So, it does not seem self-contradictory to deny that an analysis of epistemic reasons in terms of high probability holds either.

It might seem that endorsing a particular understanding of probability can avoid this problem. For instance, if an objective understanding of probability in terms of dispositions or propensities were endorsed, then in a certain sense it might be that the probability of my brother not being pregnant given the fact that he has taken his wife's birth control pills over the last year is not high because my brother's taking his wife's birth control pills over the last year does not dispose him not to get pregnant; his not having the necessary reproductive organs is all that disposes him not to get pregnant.

But endorsing an objective understanding of probability in terms of dispositions does not show that the epistemic open question argument is not compelling. This is because it is not incoherent to object to the view that for $\mathrm{R}$ to be an epistemic reason to believe $p$ is just for the probability of $p$ given $R$ to be high by denying that $R$ is an epistemic reason to believe $p$ only if the probability of $p$ given $R$ is high. Although the view that for $R$ to be an epistemic reason to believe $p$ is for $R$ to raise the probability that $p$ is not true by definition, neither does it seem to be false by definition. Bayesians who hold the view that for $R$ to be an epistemic reason to believe $p$ is for $R$ to raise the probability that $p$, would not be contradicting themselves if they claimed that $\mathrm{R}$ is an epistemic reason to believe $p$, but the probability that $p$ given $\mathrm{R}$ is not high; Bayesians would not be contradicting themselves if they claimed that the fact that I am in my office today is an epistemic reason to believe that I will die in my office today, but the probability of me dying in my office today given the fact that I am in my office today is not high. It does not seem incoherent to claim that if $\mathrm{R}$ makes $p$ more likely, then there is an epistemic reason to believe $p$. And those who hold that $R$ is an epistemic reason to believe $p$ if $R$ raises the probability that $p$, can reasonably argue with those who hold that $R$ is an epistemic reason to believe $p$ only if $R$ highly raises the probability that $p$ without either party contradicting themselves. ${ }^{30}$

So contra Heathwood, if the open question argument undermines nonnormative conceptual analyses of "is a moral reason to $\phi$," an analogous open question argument undermines nonnormative conceptual analyses of "is an epistemic reason to believe $p$. ." Just as one is not contradicting oneself if one states a view that contradicts a nonnormative

${ }^{29}$ See DiFate $(2007, \S 2(\mathrm{a}))$.

${ }^{30}$ Mark Schroeder argues that there are extremely weak massively outweighed reasons to do things, and provides an argument stemming from pragmatics as to why we sometimes think that there are no such extremely weak massively outweighed reasons. I assume that Bayesians could provide a similar argument for the view that there are extremely weak massively outweighed epistemic reasons. My point is that in arguing for or against such a view one does not seem to be contradicting oneself. See Mark Schroeder (2007) Slaves of the Passions, Oxford: Oxford University Press, 92-98. 
conceptual analysis of "is a moral reason to $\phi$," one is not contradicting oneself if one states a view that contradicts a nonnormative conceptual analysis of "is an epistemic reason to believe $p$. ." (To be clear, I do not mean to claim that the open question argument undermines either view, just that Heathwood's argument for an asymmetry regarding the plausibility of a nonnormative conceptual analysis of epistemic reasons and the plausibility of a nonnormative conceptual analysis of moral reasons fails.)

Although a naturalistic conceptual analysis of epistemic reasons is no more plausible than a naturalistic conceptual analysis of moral reasons, we might think that a metaphysical analysis or synthetic reduction of epistemic reasons to natural properties is more plausible than a metaphysical analysis or synthetic reduction of moral reasons to natural properties. But if this is the case, the many arguments against synthetic reductions of moral reasons to natural properties must not have analogues that are just as effective arguments against synthetic reductions of epistemic reasons to natural properties. So, do the many arguments against metaethical synthetic naturalism have analogues that are as effective against metaepistemological synthetic naturalism?

Consider Horgan and Timmons's moral twin-earth argument against synthetic metaethical naturalism. According to synthetic naturalists, the natural properties that direct and regulate our practice of calling things a moral reason to $\phi$ determine what is a moral reason to $\phi$. Now suppose that hedonist properties direct and regulate our practice of calling things "a moral reason." And suppose that there is a twin earth, an earth that is identical to our earth except for one feature, namely that twin-earthers' use of "is a moral reason" is directed and regulated by non-hedonist properties. So, twin-earthers say that there is a moral reason to keep any promises regardless of whether keeping a particular promise causes anyone any happiness. But we say that there is no moral reason to keep a promise if keeping it does not cause any happiness. According to Horgan and Timmons, competent users of "is a moral reason" hold that we would be disagreeing with twin-earthers in this situation, but according to synthetic naturalists, we would not be disagreeing with twin-earthers in this situation, so we should reject synthetic naturalism. ${ }^{31}$

Regardless of whether Horgan and Timmons' argument works, its epistemic analogue works just as well against synthetic naturalist analyses of epistemic reasons. Suppose that our practice of saying that a consideration "is an epistemic reason to believe $p$ " is causally regulated by (Bayesian) facts about probability-raising. So, we say that the fact that there are dinosaur bones is a reason to believe that dinosaurs once roamed the earth and the fact that I went into my office this morning is a reason to believe that I will die in my office today. But twin-earthers' practice of calling considerations "an epistemic reason to believe $p$ " is not regulated by the same properties; they do not say that the fact that I went into my office this morning is a reason to believe that I will die in my office today. According to a synthetic naturalist analysis of epistemic reasons, we do

31 See Terrence Horgan and Mark Timmons (1991) "New Wave Moral Realism Meets Moral Twin Earth," Journal of Philosophical Research 16: 447-65. 
not disagree with twin-earthers about whether the fact that I went into my office this morning is an (epistemic) reason to believe that I will die in my office today. ${ }^{32}$ But we competent users of "is an epistemic reason" hold that we would be disagreeing with twin-earthers in this situation. So, we should reject a synthetic naturalist analysis of epistemic reasons.

However good an argument against synthetic reductions of moral reasons an argument like Horgan and Timmons' is, its epistemic analogue seems as good an argument against synthetic reductions of epistemic reasons. ${ }^{33}$ So I have shown that the most well-known argument against synthetic naturalist reductions of moral reasons - and other moral properties - has an analogue that is just as effective an argument against synthetic naturalist reductions of epistemic reasons. So the burden of proof is certainly on error theorists to show that synthetic naturalistic reductions of epistemic reasons are more plausible than such reductions of moral reasons and error theorists have not as yet even attempted to discharge this burden.

But it is unclear how this burden could be discharged. Proponents of the error theory hold that revisionary accounts of moral concepts are implausible; our moral concepts entail categorical reasons and nonnormative reductive accounts cannot account for this. But the same seems true for epistemic reasons. And the fact that analogues of the open question argument and its close cousin the moral twin-earth argument can be made against nonnormative reductive accounts of epistemic reasons reaffirms that our concept of an epistemic reason for belief entails categorical rea-

\footnotetext{
32 This example could be fleshed out a little more. We could suppose that twin-earthers' practice is governed by the property of being highly probable. Or we could suppose that twin-earthers' practice is governed by hypothetico-deductivist properties, so that they only say that $R$ is an epistemic reason to believe $p$ if $p$ can be deduced from $R$ - but not in the Sherlock Holmes sense!

33 It might be objected that Horgan and Timmons' argument was not about pro tanto moral reasons, and the moral twin-earth argument is simply not plausible for pro tanto moral reasons. According to this objection, although we are confident that if our use of moral predicates at the overall level, such as "right" and "wrong," were governed by actutilitarian properties and twin-earthers' use of such overall level moral predicates were governed by Kantian properties, then we would be disagreeing with twin-earthers, we are not confident, or less confident, that if twin-earthers' and our use of pro tanto moral predicates, such as "is a moral reason," were governed by hedonist and non-hedonist properties respectively, then we would be disagreeing. But if the moral twin-earth argument is not a plausible argument against synthetic reductions of pro tanto moral predicates, this does not undermine my argument, since I have only been arguing that Horgan and Timmons' argument as an argument against synthetic naturalist reductions of (pro tanto) moral reasons has an analogue that is just as good an argument against synthetic naturalist reductions of epistemic reasons.

Horgan and Timmons' argument at the overall level also has an epistemic analogue. If our practice of calling things reasonable to believe were regulated by evidentialist properties and twin-earthers' practice was regulated by reliabilist properties, it would seem that we would be disagreeing about what is reasonable to believe. Twin-earthers would claim that Jane - who in fact has a reliable clairvoyant power and thus whose clairvoyance-based belief that the president of the U.S. is currently in Cuba is reliable, but has huge amounts of evidence that clairvoyance is impossible - is reasonable in believing that the president is currently in Cuba. We, however, would claim that Jane is not reasonable in believing that the president is currently in Cuba.
} 
sons too. But if, as error theorists hold, we cannot adopt reductive accounts of moral concepts because they entail categorical reasons, error theorists must take the same methodological approach when it comes to epistemic reasons: They must hold that since our concept of an epistemic reason entails categorical reasons, we should not accept a reductive account of epistemic reasons either. So it seems that I have vindicated premise (2) of the argument from epistemic reasons:

(2) If there are no categorical normative reasons, there are no epistemic reasons for belief.

\section{There Are Epistemic Reasons for Belief.}

According to the third premise of the argument from epistemic reasons, there are epistemic reasons for belief. Several proponents of the moral error theory, including Bart Streumer and Jonas Olson, have recently claimed that there are no epistemic reasons for belief. ${ }^{34}$ But, as I argue in this section, if there are no epistemic reasons for belief, then no one knows anything. And some people do have some knowledge.

It seems to be universally agreed by epistemologists that:

(A) If $S$ knows $p$, then there is some epistemic justification for believing $p .35$

It sounds absurd to claim that Amy knows that she was at her friend's house yesterday but she has no justification for believing that she was at her friend's house yesterday. And we always need some justification for what we believe in order to know what we believe. We can only know that it is raining outside if we have some justification for this, such as our experience of being out in the rain a few minutes ago, what we can see through the window or the sounds that we can hear coming from the roof. I can only know that I was in London yesterday if I have some justification for this, such as that I remember walking around Bloomsbury yesterday.

But we must not confuse (A) with a different claim that some reliabilists about knowledge deny. According to Steup, reliabilists about knowledge hold that "knowledge does not require justification." ${ }_{36}$ But Steup does not mean - or he is mistaken if he does - that reliabilists about knowledge hold that knowing $p$ does not require any justification for believing $p$. Reliabilists about knowledge rather hold that in order for $S$ to know $p$, $S$ 's belief that $p$ has to be true and reliably produced, but $S$ does not have to have justification for the belief that her belief that $p$ was

\footnotetext{
34 See Streumer (forthcoming) and Olson (2011).

35 Ridge emphasizes a similar point. See Michael Ridge (2007) "Expressivism and Epistemology: Epistemology for Ecumenical Expressivists," Aristotelian Society Supplementary Volume 81: 83-108, 86-87.

36 Matthias Steup (2011) "Epistemology," The Stanford Encyclopedia of Philosophy, Winter 2011 edition, E. N. Zalta, ed., plato.stanford.edu/archives/win2011/entries/ epistemology.
} 
reliably produced. ${ }^{37}$ Reliabilists about knowledge, as externalists about knowledge, are motivated to deny that our knowing $p$ involves knowing that we know $p$, but they are not motivated to deny that knowing that $p$ involves there being some justification for $p$. (Additionally, one might think that Williamson denies (A), since he holds that knowledge is primitive. But, although Williamson holds that knowledge is primitive, he still claims that knowledge entails some justification. ${ }^{38}$ )

We might think that when someone knows $p$, their justification for believing $p$ could be a non-epistemic justification for believing $p$, such as a pragmatic or prudential justification for believing $p$. But this is not plausible. Someone whose only justification for believing $p$ was a pragmatic justification would not know that $p$. If my only justification for believing that my girlfriend is not cheating on me is that it makes me happier to believe that she is not cheating on me, then I do not know that she is not cheating on me. And if I only believe in God because doing so decreases the probability of my suffering in eternal torment, then I do not know that there is a God.

It also seems that:

(B) If there is some epistemic justification for believing $p$, then there is an epistemic reason for believing $p$.

It is deeply plausible that for $p$ to justify $q$ just is for $p$ to be a reason for $q$, and that epistemic justifications just are epistemic reasons, or that epistemic reasons are just epistemic justifications. But regardless, it seems that if there is a justification for a belief, then there is a reason to believe it. It would be extremely odd to claim that I am justified in believing that dinosaurs once roamed the earth but there is no reason at all for anyone to believe this. So it seems that (B) is at least justified by default. Defenders of the error theory would have to provide a good explanation of why (B) is false in order to deny it.

With (A) and (B) in hand we can argue:

(A) If $S$ knows $p$, then there is some epistemic justification for believing $p$.

(B) If there is some epistemic justification for believing $p$, then there is an epistemic reason to believe $p$.

So,

(C) If $S$ knows $p$, then there is an epistemic reason to believe $p$ (A, B).

Given this argument, in order to establish that there are epistemic reasons for belief we only need to establish that someone knows something. I know my phone number; I can quite easily demonstrate this. One thing I know is that I do not know everything. Furthermore, when I think right now I know that there is thought. I also know right now that bache-

${ }^{37}$ See, for instance, Fred Dretske (1989) "The Need to Know," in Marjorie Clay and Keith Lehrer, eds., Knowledge and Skepticism, Boulder: Westview Press, 89-100, 95.

38 See Timothy Williamson (2000) Knowledge and Its Limits, Oxford: Clarendon Press, p. 57 and Timothy Williamson (2009) "Replies to Critics," in Patrick Greenough and Duncan Pritchard, eds., Williamson on Knowledge, Oxford: Oxford University Press, 279-384, 300 . 
lors are not women. It is hard to understand how I could not know these things. Just by looking at the grass outside I know that I do not know what it is made of. I do not know the programming language this word processor (that I am using) was written in. Just by understanding the meaning of "bachelor" I know that a bachelor is not a woman. And just in virtue of minimally understanding what it means to be thinking I know that I am thinking, or, if we want to follow a less Cartesian view, just in virtue of minimally understanding what thought is I understand that right now there is thought. So long as I believe that there is thought I am right that there is thought - I could not be wrong about it - and so long as I believe that there is thought on the basis that I am thinking right now, my belief that there is thought is based in an appropriate way for me to know that there is thought. So it is false that no one knows anything, since I know that there is thought right now.

If I know that there is thought, I have some justification for believing that there is thought (A), and if I have some justification for believing that there is thought, I have an epistemic reason for believing that there is thought (B). So there are epistemic reasons. So, it seems that I have vindicated premise (3) of the argument from epistemic reasons:

(3) But there are epistemic reasons for belief.

Defenders of the error theory might respond to this argument for (3) by adopting a revisionary account of reasons or knowledge, which would allow them to claim that $S$ knows $p$ does not entail that there is an epistemic reason to believe that $p$. For instance, defenders of the error theory might hold an account of all reasons according to which all reasons, including epistemic reasons, are analyzed in terms of desire-promotion, and then claim that $S$ knows $p$ does not entail that there is an epistemic reason to believe that $p$ because $S$ may know that $p$, but believing $p$ might not promote her nor anyone else's desires. But defenders of the error theory reject all revisionary accounts of categorical reasons as well as other facts; that is why they are error theorists and not reductive naturalists. I do not see what the justification would be for rejecting all revisionary accounts of categorical reasons and other moral facts but holding a revisionary account of knowledge. Taking this strategy would conflict with error theorists' methodological approach to understanding other concepts, namely moral concepts.

In this section, I vindicated premise (3) of the argument from epistemic reasons and in the last section I vindicated premises (1) and (2). So I can now argue:

(1) According to the moral error theory, there are no categorical normative reasons.

(2) If there are no categorical normative reasons, then there are no epistemic reasons for belief.

(3) But there are epistemic reasons for belief.

(4) So there are categorical normative reasons $(2,3)$.

(5) So, the error theory is false $(1,4)$. 


\section{Moorean Arguments Against the Error Theory}

I have been defending the argument from epistemic reasons against the moral error theory. But error theorists might object to the argument from epistemic reasons, or at least my way of defending it, on the grounds that this argument is just another Moorean argument against the error theory.

Ronald Dworkin, Thomas Nagel and Michael Huemer have defended what is sometimes called the Moorean argument against the moral error theory. ${ }^{39}$ I will call this the old Moorean argument against the moral error theory. According to this argument:

The Old Moorean Argument against the Moral Error Theory

If the moral error theory were true, then torturing innocent children just for fun would not be wrong.

It seems to me more certain that torturing innocent children just for fun is wrong than that any of the premises in support of the error theory are true.

So,

The error theory is false.

I present the old Moorean argument as it is presented in the literature. Of course, there is a missing third premise in this argument, which is something like: If $P$ entails not- $Q$, and I am more certain that $P$ than that $Q$, other things being equal, $P$ and not- $Q$. It strikes me that this is a good principle if slightly modified to: If $P$ entails not- $Q$, and I am more certain that $P$ than that $Q$, other things being equal, I should hold that $P$ and notQ. I assume that nothing important hangs on whether the principle should be modified in this way and whether Moorean arguments should be modified to reflect this modified principle.

Error theorists might claim that the way I have defended the argument from epistemic reasons looks suspiciously like the following Moorean argument against the moral error theory:

The New Moorean Argument against the Moral Error Theory

If the moral error theory is true, then no one knows anything.

It seems to me more certain that I know that there is thought when I am

thinking and that I know that I do not know everything than that any of the premises supporting the moral error theory are true.

So,

The moral error theory is false.

Recently Bart Streumer, Tristram McPherson and Jonas Olson have provided arguments against the old Moorean argument against the moral error theory. And we would expect these arguments to carry over and undermine this new Moorean argument against the moral error theory. But, as I will argue, Olson's, McPherson's and Streumer's arguments do not afflict the new argument against the moral error theory, even if they

39 See Ronald Dworkin (1996) "Objectivity and Truth: You'd Better Believe It," Philosophy and Public Affairs 25: 87-139, 117-18; Michael Huemer (2005) Ethical Intuitionism, New York: Palgrave Macmillan, 115-17; Thomas Nagel (1997) The Last Word, New York: Oxford, p. 115; and Tristram McPherson (2009) "Moorean Arguments and Moral Revisionism," Journal of Ethics and Social Philosophy 3: 2. 
afflict the old one, and the new Moorean argument against the moral error theory is stronger than the Moorean argument against external world skepticism. So if my way of articulating the argument from epistemic reasons makes it into a Moore-style argument against the error theory, this is not a problem for my argument.

\section{i. Olson on the old Moorean argument}

According to the old Moorean argument, we should reject the error theory because it entails that torturing innocent children for fun is not wrong, but we are more certain that torturing innocent children for fun is wrong than that any of the premises supporting the error theory are true. Jonas Olson has argued that the old Moorean argument is unsuccessful because once we take evolutionary-debunking explanations of morality into consideration we are no longer so certain that torturing innocent children for fun is wrong. According to Olson, the survival-promoting effects of morality produced our beliefs in morality and our high level of certainty that torturing innocent children for fun is wrong, but our moral beliefs might be both survival-promoting and false, and thus our moral beliefs and certainty regarding moral claims are not a good guide to the truth. Once we realize this, "it is far from clear that we are more certain that some actions - such as torturing animals or children for fun - really are morally wrong than we are that there are ... no moral truths" or that any of the premises supporting the moral error theory are true. 40

Even if Olson is right about this, the new Moorean argument cannot be undermined in the same way. Evolutionary-debunking explanations of morality purport to establish that, for instance, if torturing innocent children for fun were not wrong, we would still believe that it is wrong. ${ }^{41}$ If they can establish this, they can perhaps undermine our certainty that torturing children for fun is wrong. But so long as we believe that we know that there is thought, there is thought. There is no circumstance in which we mistakenly believe that there is thought. So there is no way to undermine our certainty that there is thought. And if there is no way at all to undermine our certainty that there is thought, there is no way of (evolutionarily) undermining our belief that we know that there is thought.

Olson might run a different argument. He might claim that regardless of whether our subjective certainty in our knowing that there is thought, or knowing that we do not know things, can be undermined, our beliefs about knowledge in general can be evolutionarily debunked, and this is sufficient to undermine the new Moorean argument. Although no one has proposed such a debunking explanation of knowledge, we can perhaps imagine one: Believing that people know things facilitated coop-

40 Olson (2010: 66-67).

${ }^{41}$ See, for instance, Michael Ruse (1986) Taking Darwin Seriously, Oxford: Blackwell, pp. 251-54; Richard Joyce (2006) The Evolution of Morality, Cambridge, MA: MIT Press, ch. 6; and Sharon Street (2006) "A Darwinian Dilemma for Realist Theories of Value," Philosophical Studies 127: 109-66, especially 121-22. 
eration and coordination among our ancestors and raised their prospects of survival. There are two problems with such an explanation.

First, we can argue that there is no debunking to be had here. If cooperation and coordination were facilitated by talking about knowledge, this was probably because some processes were more likely to yield true beliefs, and calling beliefs yielded by these processes knowledge and calling people more likely to have true beliefs "knowers" allowed our ancestors to have more true beliefs. But, in this case, presumably beliefs generated by these processes were knowledge because they were generated by processes more likely to yield true beliefs. If these beliefs had not been generated by reliable processes, our ancestors would not have called them knowledge because it would not have facilitated cooperation and coordination to call beliefs yielded by processes that were not more likely to yield true beliefs knowledge. 42

Secondly, if our beliefs in knowledge can be debunked just because believing that people knew things facilitated cooperation and coordination among our ancestors and raised their prospects of survival, then pretty much all our beliefs about anything can be debunked. If all it takes to undermine a belief in $p$ is for it to be the case that even if not- $p$ it would have benefitted our ancestors to some extent to believe $p$, then virtually all of our beliefs can be debunked. It would have benefitted our ancestors to believe that, for instance, there were tables even if it were not the case that atoms arranged tablewise compose tables. Similarly, mutatis mutandis with regards to grass, windows, fans, baseballs, people, etc. ${ }^{43}$ So we should reject such a low standard for a debunking explanation because such a low standard would entail that virtually all of our beliefs, as presently understood, could be debunked. Note that even proponents of debunking explanations do not hold that virtually all our beliefs can be debunked. ${ }^{44}$

\section{ii. McPherson on the old Moorean argument}

The Moorean argument against the moral error theory gets its name from Moore's argument against external skepticism, according to which:

The Moorean Argument against External World Skepticism

If the external world did not exist, I would not have hands.

It seems to me more certain that I have hands than that any of the premises in support of external world skepticism are true, no matter all of them.

So,

The external world exists. ${ }^{45}$

42 See, for instance, Miranda Fricker (2008) "Skepticism and the Genealogy of Knowledge: Situating Epistemology in Time," Philosophical Papers 37: 27-50.

${ }^{43}$ See Justin Clarke-Doane (2012) "Morality and Mathematics: The Evolutionary Challenge," Ethics 122: 313-40, 323.

44 See, for instance, Joyce (2006: 179-82).

45 See McPherson (2009: 4) and G. E. Moore (1959) "Four Forms of Skepticism," Philosophical Papers, London: George Allen and Unwin, pp. 198-226, 226. 
According to Tristram McPherson, whatever we think about the Moorean argument against external world skepticism, we should hold that the old Moorean argument against the moral error theory is weaker than the Moorean argument against external world skepticism.

McPherson argues that we should evaluate Moorean arguments on the basis of five indicators:

(a) Relative confidence in the Moorean claim and the revisionary claim or thesis.

(b) Prevalence of philosophically naïve proponents of the revisionary claim or thesis.

(c) Extent and nature of the reorganization of our beliefs required by the revisionary claim or thesis.

(d) Relative consilience of the Moorean premise and the revision with our epistemic paradigms.

(e) Vulnerability of the Moorean premise to debunking explanations.

McPherson claims that the Moorean argument against external world skepticism does pretty well on these indicators and the old Moorean argument against the moral error theory does not.46

According to McPherson, both the old Moorean argument against the error theory and the argument against external world skepticism do well on (a). But regarding (b), there is more support for moral skepticism than there is for external world skepticism among the philosophically naive, and the error theory is a type of moral skepticism. Regarding (c), accepting external world skepticism would require "massive and deep adjustment to one's set of beliefs" while the moral error theory only requires a localized adjustment of beliefs, that is, it only requires adjustment to one's moral beliefs. ${ }^{47}$ Regarding (d), McPherson claims that external world skepticism:

threatens to undermine most of our ordinary epistemic paradigms concerning the day-to-day management of belief, and also the status of our best scientific theories as methodological paradigms, at least on the assumption that those theories purport to describe elements of the external world. ${ }^{48}$

But the moral error theory fails to threaten our epistemic paradigms, such as "beliefs about our perceptual access to medium-sized dry goods, the legitimacy of induction and the deliverances of physics." ${ }_{49}$ Finally, regarding (e), the moral premise of the Moorean argument against the moral error theory - torturing children for fun is wrong - is vulnerable to debunking explanations, whereas the claim "I have hands" is not. ${ }^{50}$

The new Moorean argument against the moral error theory fares much better on McPherson's five indicators than the old Moorean argument against the moral error theory. Regarding indicator (b), there is even less philosophically naïve support for the claim that no one knows any-

46 See McPherson (2009: 14-15).

47 Ibid., 9-11.

48 Ibid., 10.

${ }^{49}$ Ibid., 12.

50 Ibid., 10 and 13-14. 
thing than there is for external world skepticism. Some people who are obsessed with the movie The Matrix may believe in external world skepticism, but they do not believe that no one knows that there is thought when they are thinking, or that no one knows that they do not know everything.

Regarding (c), the new Moorean argument shows that, like external world skepticism, accepting the moral error theory would require a deep and massive adjustment to our beliefs because it entails that no one knows anything. We believe that we know many things about ourselves, about our history and about the world around us. At least a great deal and wide variety of our beliefs are based on what we regard as knowledge. If I did not have the belief that I have some elementary mathematical knowledge, for instance, I would not have many beliefs that I currently have, such as that I am owed \$156.02 in conference expenses. Regarding (d), the new Moorean argument shows that, like external world skepticism, the moral error theory threatens to undermine most of our ordinary epistemic paradigms such as that scientists have methods for acquiring knowledge, that physics is a body of knowledge and that we have perceptual knowledge.

Finally, as I argued in the last section, regarding (e), the claims, "some people have some knowledge," "I know my phone number" and "I do not know everything," are not vulnerable to debunking explanations.

So, the new Moorean argument against the moral error theory fares at least as well on McPherson's indicators as the Moorean argument against external world skepticism. In fact, the new Moorean argument is a stronger argument than Moore's argument against external world skepticism. One of the claims that the new Moorean argument is arguing against, namely that no one knows anything, is even less prevalent than external world skepticism: Surely even the most entrenched skeptic will allow that we know that we do not know everything.

Furthermore, external world skeptics justify external world skepticism by appealing to skeptical scenarios. According to them, we can imagine two cases: the good case and the bad case. In the good case I have all the same visual, tactile, auditory and other sense experiences that I have now, and these experiences are veridical, that is, the world in fact is as it seems to me; it seems to me that I have hands, and I do in fact have hands. In the bad case I have all the same visual, tactile, auditory and other sense experiences that I have now, but these experiences are non-veridical, that is, the world is not as it seems to me because my sense experiences are being manipulated by an evil demon or a race of machines; it seems to me that I have hands, but in fact I do not have hands. But the good case and the bad case are introspectively indistinguishable and external world skeptics take this introspective indistinguishability to establish that I cannot know whether I am now in the good case or the bad case; I cannot know whether I have hands or not.

But there is no similar skeptical scenario that can be wielded to undermine the claim that when I am thinking I know that there is thought. There is no bad case in which we believe that we know that we are think- 
ing, or that there is thought, in which we are mistaken that we know that we are thinking, or that there is thought, when we are thinking. When we are thinking the fact that we are thinking ensures that there is thought, and so if I believe that I know that there is thought, I do know that there is thought. Similarly, there is no bad case in which I believe that I do not know everything, but in fact I do know everything. So the Moorean premise of the new Moorean argument against the error theory is better justified than the Moorean premise of the Moorean argument against external world skepticism.

So, the new Moorean argument is a stronger argument than the old Moorean argument against the error theory and Moore's argument against external world skepticism. But, to clarify, this does not mean that there is a good Moorean argument that shows that there are epistemic reasons but no good Moorean argument that shows that the moral error theory is false. The new Moorean argument that I have been defending in this section is an argument against the moral error theory. According to this argument,

The New Moorean Argument against the Moral Error Theory

If the moral error theory is true, then no one knows anything.

It seems to me more certain that I know that there is thought when I am thinking and that I know that I do not know everything than that any of the premises supporting the moral error theory are true.

So,

The moral error theory is false.

I supported the first premise of this argument, namely, if the moral error theory is true then no one knows anything, in sections 2 and 3 above. So, even if McPherson is right that the old Moorean argument against the moral error theory does not fare as well as the Moorean argument against external world skepticism, there is still a powerful Moorean argument against the moral error theory that is a stronger argument than Moore's argument against external world skepticism.

\section{iii. Streumer on the old Moorean argument}

Bart Streumer recently provided a novel argument against the old Moorean argument. In order to discuss Streumer's argument we need to modify the old Moorean argument a little. ${ }^{51}$ According to Streumer's variant of the argument:

The Old Moorean Argument

The error theory entails that torturing innocent children for fun is not wrong

The claim that torturing innocent children for fun is wrong is clearly much more plausible than the error theory

So,

51 If the Moorean argument is presented in terms of degrees of certainty as above, Streumer's objection to the argument does not appear to get off the ground. 
We should reject the error theory. 52

Streumer claims that this argument depends on:

Principle. If a claim $\mathrm{C}$ and a philosophical theory $\mathrm{T}$ cannot both be true, and if $\mathrm{C}$ is much more plausible than $\mathrm{T}$, we should reject $\mathrm{T}$.

Streumer presumes that "plausible" in Principle either means "seems true" or "there is reason to believe it." ${ }_{53}$ But Streumer claims that regardless of whether plausible means "seems true" or "there is reason to believe it," Principle does not apply when $\mathrm{T}$ is the normative error theory - the view that there are no normative reasons for anything - because:

(iv). No one can believe the normative error theory.

And if no one can believe the normative error theory,

(v.) There is no reason for anyone to believe the normative error theory.

Streumer presents the following argument for (iv) and (v):

(i) Anyone who understands the normative error theory well enough to be in a position to believe it knows that if the normative error theory is true, then there are no normative reasons.

(ii) No one can both believe $p$ and believe that there is no reason to believe $p .54$

(iii) If there is a normative reason for $A$ to $\phi$ (such as to believe $p$ ), $A$ must be able to $\phi .55$

Therefore,

(iv) No one can believe the normative error theory (i, ii).

And,

(v) There is no reason for anyone to believe the normative error theory (iii, iv).

Armed with (iv), Streumer can argue that if "plausible" in Principle means "seems true," Principle does not apply when theory $\mathrm{T}$ is the normative error theory because "what explains why $\mathrm{C}$ seems much more clearly true than $\mathrm{T}$ is not that $\mathrm{C}$ actually is true, but is instead that we cannot believe T." Armed with (v), Streumer can argue that if "plausible" in Principle means "there is reason to believe it," Principle does not apply when T is the error theory because "what explains why there is much more reason to believe $\mathrm{C}$ than to believe $\mathrm{T}$ is not that $\mathrm{C}$ is more likely to be true than $\mathrm{T}$, but is instead that, since we cannot believe $\mathrm{T}$, there is no reason for us to believe T." ${ }_{56}$

The new Moorean argument can circumvent Streumer's objection to the old Moorean argument. We can translate the new Moorean argument

\footnotetext{
52 Streumer (forthcoming: 17-18). (References are from the version available at: www.personal.rdg.ac.uk/ lds05bs/BelieveErrorTheory.pdf.)

53 Ibid., 18-19.

54 Ibid., 2-7.

55 Ibid., 8-11.

56 Ibid., 18-19.
} 
into the same style as Streumer's understanding of the old Moorean argument in the following way:

The New Moorean Argument

(I) The error theory entails both that I do not know that there is thought when I am thinking and that no one knows anything.

(II) It is far more plausible that I know that there is thought when I am thinking than that no one knows anything.

Principle. If a claim $\mathrm{C}$ and a philosophical theory $\mathrm{T}$ cannot both be true, and if $\mathrm{C}$ is much more plausible than $\mathrm{T}$, we should reject $\mathrm{T}$.

So,

(III) We should reject the claim that no one knows anything (II, Principle).

Modus Tollens Principle. if we should reject $q, p$ entails $q$ and we understand that $p$ entails $q$, we should reject $p$.

(IV) If we should reject the claim that no one knows anything, then we should reject the error theory (I, III, Modus Tollens Principle).

So,

(V) We should reject the error theory (III, IV).

Streumer cannot respond to the new Moorean argument in the same way that he responded to the old Moorean argument. Streumer's response was: that we cannot believe the normative error theory or that there cannot be a reason to believe the normative error theory explains why we find the claim that torturing children for fun is wrong more plausible than the normative error theory. But that we cannot believe the normative error theory or that there cannot be a reason to believe the normative error theory cannot explain why we find the claim that we know that there is thought more plausible than the claim that no one knows anything. That we cannot believe the normative error theory cannot explain this because the claim that no one knows anything does not depend on the error theory. The claim that no one knows anything does not entail the error theory or that there are no epistemic reasons. One might, for instance, hold that we have no knowledge, but that we are justified in believing certain things, and thus hold that no one knows anything but claim that there are epistemic reasons.

That we cannot believe that no one knows anything could not explain why we find this claim far less plausible than the claim that when we are thinking we know that there is thought. There is no evidence that we cannot believe that no one knows anything; even if Streumer is right that we cannot both believe $p$ and believe that there is no reason to believe $p$, I can certainly believe $p$ without believing that I know $p$. Since there is no evidence that we cannot believe that no one knows anything, there is no evidence that there is a disabling condition preventing there being a reason to believe that no one knows anything. So, Streumer's strategy for arguing against the old Moorean argument cannot be transposed to argue against the new Moorean argument. 


\section{Conclusion}

\section{I have been defending:}

The Argument from Epistemic Reasons

(1) According to the error theory there are no categorical normative reasons.

(2) If there are no categorical normative reasons, then there are no epistemic reasons for belief.

(3) But there are epistemic reasons for belief.

(4) So there are categorical normative reasons $(2,3)$.

(5) So, the error theory is false $(1,4)$.

I have shown that the argument from epistemic reasons is a strong argument against the moral error theory. In section 2, I vindicated premise (2) and in section 3, I vindicated premise (3). In the last section, I have shown that even if the way I have articulated and defended the argument from epistemic reasons makes it a Moorean argument against the moral error theory, this Moorean argument evades Streumer's, McPherson's and Olson's previous objections to Moorean arguments against the error theory and is a stronger Moorean argument than Moore's argument against external world skepticism..$^{57}$

Richard Rowland

University of Reading

Department of Philosophy

r.a.rowland@pgr.reading.ac.uk

57 I would like to thank Matthew Chrisman, Brad Hooker, Noa Leibowitz, Scott Normand, Jonas Olson, Anthony Price, Philip Stratton-Lake, Bart Streumer and an anonymous referee for comments on and discussions of previous drafts, as well as the audiences at Reading, Leeds and the BPPA annual conference 2012 at Edinburgh. An Arts and Humanities Research Council studentship funded the writing of this paper. 